\title{
Dengue infection severity score - improvised disease management
}

This article was published in the following Dove Press journal:

Risk Management and Healthcare Policy

16 August 2016

Number of times this article has been viewed

\section{Syed Uzair Mahmood' Maryam Jamil Syed' \\ Aisha Jamal' \\ Maria Shoaib ${ }^{2}$}

'Sindh Medical College, Jinnah Sindh Medical University, Karachi, Pakistan; ${ }^{2}$ Dow Medical College, Dow University of Health Sciences, Karachi, Pakistan
Correspondence: Syed Uzair Mahmood 43-8-D, Block 6, Pechs, Karachi, Pakistan Tel +92 33I 846 I557

Email uzair.hbb@gmail.com

\section{Dear editor}

We would like to add our views regarding the paper "Validation of Dengue infection severity score" by Pongpan et al. ${ }^{1}$ As the paper outlines, the purpose of the Dengue Severity Score is to classify individuals with dengue infection into three levels of severity with clinically acceptable underestimation or overestimation.

Dengue virus is transmitted by Aedes mosquitoes, which are sensitive to various environmental conditions including temperature, rainfall, and humidity. These factors are critical to mosquito reproduction and survival, for example, higher temperatures decrease the time required for virus replication and dissemination in the Aedes mosquito. ${ }^{2}$ The incidence of dengue doubles every decade, it increased from 8.3 million apparent cases in 1990 to 58.4 million apparent cases in 2013. ${ }^{3}$ Although it is a preventable disease, dengue still has an estimated mortality rate of 20,000 people per year. ${ }^{2}$ The clinical presentation of dengue infection is characterized by fever, headache, vomiting, muscle and joint pain, as well as rash on the skin. Complicated cases may result in hemorrhagic fever, thrombocytopenia, shock, and death.

The World Health Organization classification of dengue fever (2009) includes two separate entities, namely, dengue and severe dengue; however, this has yet to be proven as clinically significant. Very few studies are available, and of them, most are at a secondary or tertiary level of care and not at the level of primary care. Most studies are not carried out in resource-poor settings. ${ }^{4}$ This World Health Organization gross classification is not practical since dengue epidemic affects a wide range of age groups and manifests as different clinical presentations globally, thus adding diversity to disease spectrum. ${ }^{5}$

Dengue infection severity score is a handy assessment tool; prerequisite information required for this include patients' clinical data consisting of their medical history, recorded vitals, complete blood count, history of bleeding episodes with results of tourniquet tests, and recent incidents of plasma leakage determined by assessing hemoconcentration, which shows a $20 \%$ increase in hematocrit. In our opinion, utilizing the clinical data in the scoring system would allow for more efficient and cost-effective patient care and may minimize unnecessary hospitalization as patients with a low score are suspected to have dengue fever and could be examined and treated as outpatients, while those with a greater score are suspected of dengue hemorrhagic fever and could be admitted in the hospital. Finally, those with the greatest score, likely to have dengue shock syndrome, could be admitted for immediate monitoring in an intensive care unit. 
We suggest that the scoring system should be made widely applicable to effectively manage the ongoing changes being currently observed in the virulence factors of dengue virus, for example, a fifth serotype DENV-5 recently discovered in 2015 , has been shown to have caused frequent epidemics and life-threatening mortalities. ${ }^{5} \mathrm{We}$ recommend this resourceful and impactful scoring system for efficient hospital care and management of dengue patients.

\section{Disclosure}

The authors report no conflicts of interest in this work.

\section{References}

1. Pongpan S, Patumanond J, Wisitwong A, Tawichasri C, Namwongprom S. Validation of dengue infection severity score. Risk Manag Healthc Policy. 2014;7:45-9.

2. Carabali M, Hernandez LM, Arauz MJ, Villar LA, Ridde V. Why are people with dengue dying? A scoping review of determinants for dengue mortality. BMC Infect Dis. 2015;15:301.

3. Stanaway JD, Shepard DS, Undurraga EA, et al. The global burden of dengue: an analysis from the Global Burden of Disease Study 2013. Lancet Infect Dis. 2016;16(6):712-723.

4. Centers for Disease Control and Prevention. Dengue and Climate, 2012. Available at: http://www.cdc.gov/dengue/entomologyEcology/climate. html.

5. Hadinegoro SR. The revised WHO dengue case classification: does the system need to be modified? Paediatr Int Child Health. 2012;32(Suppl 1): 33-38.

Dove Medical Press encourages responsible, free and frank academic debate. The content of the Risk Management and Healthcare Policy 'letters to the editor' section does not necessarily represent the views of Dove Medical Press, its officers, agents, employees, related entities or the Risk Management and Healthcare Policy editors. While all reasonable steps have been taken to confirm the content of each letter, Dove Medical Press accepts no liability in respect of the content of any letter, nor is it responsible for the content and accuracy of any letter to the editor.

\section{Risk Management and Healthcare Policy}

\section{Publish your work in this journal}

Risk Management and Healthcare Policy is an international, peer-reviewed, open access journal focusing on all aspects of public health, policy, and preventative measures to promote good health and improve morbidity and mortality in the population. The journal welcomes submitted papers covering original research, basic science, clinical and epidemiological
Dovepress

studies, reviews and evaluations, guidelines, expert opinion and commentary, case reports and extended reports. The manuscript management system is completely online and includes a very quick and fair peerreview system, which is all easy to use. Visit http://www.dovepress.com/ testimonials.php to read real quotes from published authors.

Submit your manuscript here: https://www.dovepress.com/risk-management-and-healthcare-policy-journal 